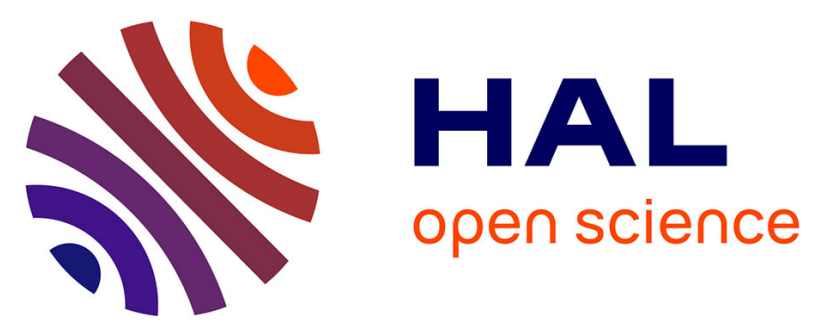

\title{
Analysis of satellite gravity and bathymetry data over Ninety-East Ridge: Variation in the compensation mechanism and implication for emplacement process
}

V.M. Tiwari, M Diament, S. C. Singh

\section{- To cite this version:}

V.M. Tiwari, M Diament, S. C. Singh. Analysis of satellite gravity and bathymetry data over NinetyEast Ridge: Variation in the compensation mechanism and implication for emplacement process. Journal of Geophysical Research: Solid Earth, 2003, 108 (B2), 10.1029/2000JB000047 . insu-01356385

HAL Id: insu-01356385

https://hal-insu.archives-ouvertes.fr/insu-01356385

Submitted on 25 Aug 2016

HAL is a multi-disciplinary open access archive for the deposit and dissemination of scientific research documents, whether they are published or not. The documents may come from teaching and research institutions in France or abroad, or from public or private research centers.
L'archive ouverte pluridisciplinaire HAL, est destinée au dépôt et à la diffusion de documents scientifiques de niveau recherche, publiés ou non, émanant des établissements d'enseignement et de recherche français ou étrangers, des laboratoires publics ou privés. 


\title{
Analysis of satellite gravity and bathymetry data over Ninety-East Ridge: Variation in the compensation mechanism and implication for emplacement process
}

\author{
V. M. Tiwari \\ National Geophysical Research Institute, Hyderabad, India \\ M. Diament and S. C. Singh \\ Institut de Physique du Globe de Paris, Paris, France \\ Received 7 November 2000; revised 14 June 2002; accepted 3 July 2002; published 20 February 2003. \\ [1] We investigate the mode of compensation, emplacement history and deep density \\ structure of the Ninety-East Ridge (Indian Ocean) using spectral analyses and forward \\ modeling of satellite gravity and bathymetry data. We find that the northern $\left(0-10^{\circ} \mathrm{N}\right)$ and \\ the southern $\left(20-30^{\circ} \mathrm{S}\right)$ parts of the ridge are flexurally compensated with an effective \\ elastic thickness $>15 \mathrm{~km}$, whereas the central part $\left(0-20^{\circ} \mathrm{S}\right)$ is locally compensated. \\ Furthermore, we find that for a part of central block $\left(10-20^{\circ} \mathrm{S}\right.$, over Osborn Knoll) the \\ compensation depth is unreasonably very high $(30-40 \mathrm{~km})$. Therefore we favor a model \\ with subsurface loading and interpret this to be due to underplating of mafic material at the \\ base of the crust, a hypothesis that is supported by seismic results and direct modeling \\ of gravity data along some profiles. These results suggest that the northern and southern \\ parts of Ninety-East Ridge were emplaced off to a ridge axis compared to the central one, \\ which might have been emplaced on or near a spreading center. Locally compensated \\ large topography, thick underplated crust in the central part (near Osborn Knoll), might \\ result from an interaction of a hot spot with the extinct Wharton spreading ridge. INDEX \\ TERMS: 1219 Geodesy and Gravity: Local gravity anomalies and crustal structure; 1234 Geodesy and Gravity: \\ Regional and global gravity anomalies and Earth structure; 1236 Geodesy and Gravity: Rheology of the \\ lithosphere and mantle (8160); KEYWORDS: Ninety-East Ridge, gravity, isostasy, hot spot, on- and off-ridge \\ axis volcanism
}

Citation: Tiwari, V. M., M. Diament, and S. C. Singh, Analysis of satellite gravity and bathymetry data over Ninety-East Ridge: Variation in the compensation mechanism and implication for emplacement process, J. Geophys. Res., 108(B2), 2109,

doi:10.1029/2000JB000047, 2003.

\section{Introduction}

[2] Ninety-East Ridge (NER) (Figure 1) is a $\sim 5000 \mathrm{~km}$ long linear bathymetric feature strikes NNE-SSW along $90^{\circ} \mathrm{E}$ longitude and is noticable between $31^{\circ} \mathrm{S}$ and $9^{\circ} \mathrm{N}$ latitude. The ridge is elevated $\sim 2-3 \mathrm{~km}$ above the adjacent seafloor and its width varies from 150 to 250 $\mathrm{km}$. It is the most prominent feature in the eastern Indian Ocean and separates the central Indian basin on the west from the Wharton basin on the east [Sclater and Fisher, 1974]. Several models have been put forward for the origin of the NER; however, it is widely believed that NER is a volcanic trace due to hot spot(s) [e.g., Morgan, 1972; Luyendyk and Rennick, 1977; Curray et al., 1982; Duncan, 1991]. Deep-sea drilling results give a monotonic decrease in age from north to south and suggest a hot spotrelated volcanism near a mid oceanic ridge axis [Frey and Weis, 1995, and references therein]. Magnetic anomalies recorded in this region (Figure 2) reveal an increase in age

Copyright 2003 by the American Geophysical Union. 0148-0227/03/2000JB000047\$09.00 from south to north in the west of the NER, but the age does not decrease or increase monotonically in the east of the NER. Discontinuity in the magnetic anomaly east of the NER, led Liu et al. [1983] to suggest an east-west spreading center in the Wharton basin, christened as Wharton spreading center. This spreading center was ceased at $\sim 40$ m.y. ago and was followed by the initiation of seafloor spreading along the southeast Indian Ridge [Liu et al., 1983; Royer et al., 1991]. Royer and Sandwell [1989] and Royer et al. [1991] postulated several southward jumps and extension of the Wharton spreading center up to the NER. Recently, Krishna et al. [1995] proposed an abandoned spreading center even in the west of NER, which joins the southeast Indian Ridge. In such a scenario, the emplacement of NER relative to a spreading center becomes more complex. However, on the basis of magnetic anomaly and compilation of other results, Royer et al. [1991] proposed that the northern part (north of $2^{\circ} \mathrm{S}$ ) of the NER was formed because of intraplate volcanism, whereas the southern part (south $15^{\circ} \mathrm{S}$ ) was formed along a fracture zone by the Kerguelen hot spot. 


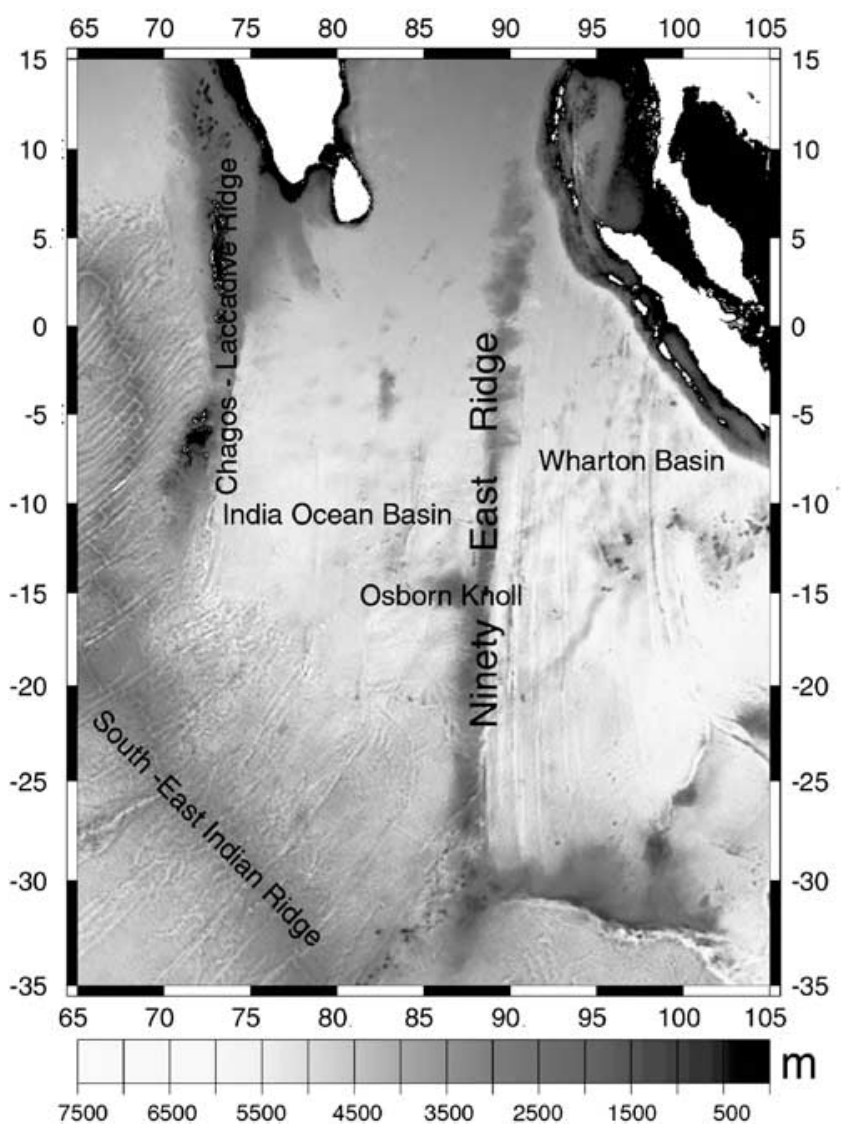

Figure 1. Bathymetry of the central Indian Ocean [Smith and Sandwell, 1997] showing ridges and ocean basins.

[3] Isostatic study of ocean topographic loads provides information about the mechanical behavior of lithosphere at the time of loading [e.g., Watts et al., 1980] and therefore allows one to investigate emplacement mechanisms of bathymetric features [e.g., Diament and Goslin, 1986]). Isostasy is also related to the deep density structure. Therefore study of isostasy can provide constraints on geological models for the origin of NER, which are until now based mainly on deep drilling results and magnetic anomalies. Earlier isostatic studies of NER [Bowin, 1973; Detrick and Watts, 1989; Hébert et al., 1996; Grevemeyer and Flueh, 2000] are concentrated near the equator or south of it due to the limited amount of ship data available and suggest that this part of NER was emplaced over a spreading center, which is in agreement with the hypothesis of Royer et al. [1991]. However, such analysis have not been carried out for the northern and southern parts of NER. In the present study, we analyze the satellite-derived and ship-borne data to investigate the possible variations in the compensation mechanism, vis-à-vis the emplacement processes (i.e., onridge versus off-ridge) and deep density structure all along the NER. We also discuss a possible interaction of a hot spot with the extinct Wharton spreading ridge.

\section{Data Analysis}

[4] Satellite gravity data provide vital information about unexplored areas of the ocean [Sandwell, 1991]. Their accuracy varies from region to region but for deep ocean $(>2000 \mathrm{~m})$ it is quite good (5-10 mGal) [Rapp, 1998]. We compared these data with sea surface gravity and bathymetry data acquired along a 2000-km-long profile following $7.5^{\circ} \mathrm{S}$ latitude which cuts the NER [Hébert et al., 1996]. Figure 3 shows that ship-borne and satellite-derived data sets compare quite well in the amplitude (Figure 3a) and for wavelengths larger than $20 \mathrm{~km}$ (Figure 3b). A good coherency between ship-borne bathymetry and bathymetry by Smith and Sandwell [1997] for wavelengths $>100 \mathrm{~km}$ (Figure $3 b)$ suggests that later bathymetry data set can be used for isostatic study. However, in the intermediate wavelengths (20-150 km), Smith and Sandwell's [1997] bathymetry data

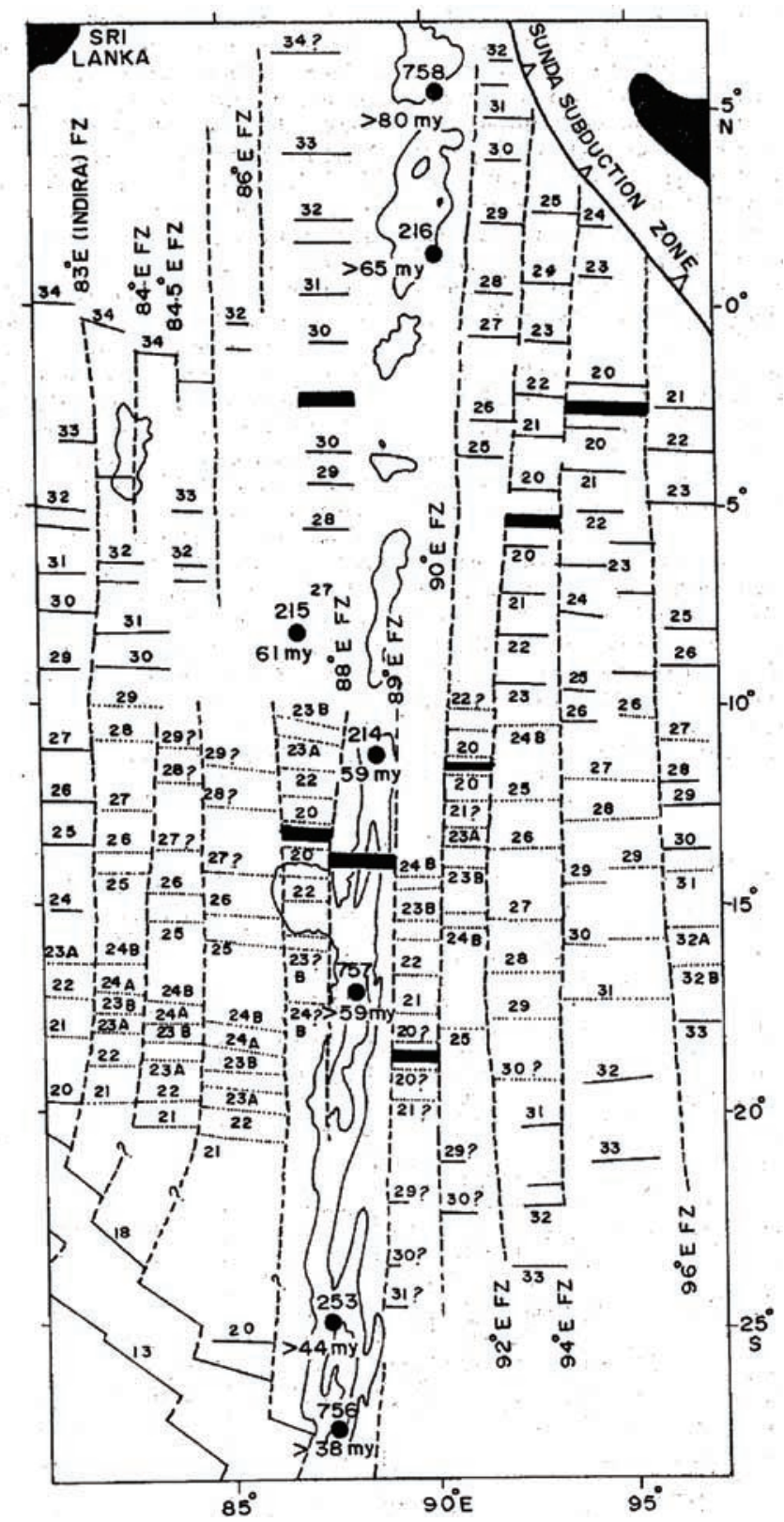

Figure 2. Tectonic map of the surrounding area of NinetyEast Ridge with magnetic lineation, fossil spreading center (solid boxes) and fracture zones (dashed line) [after Krishna et al., 1995]. 
a)

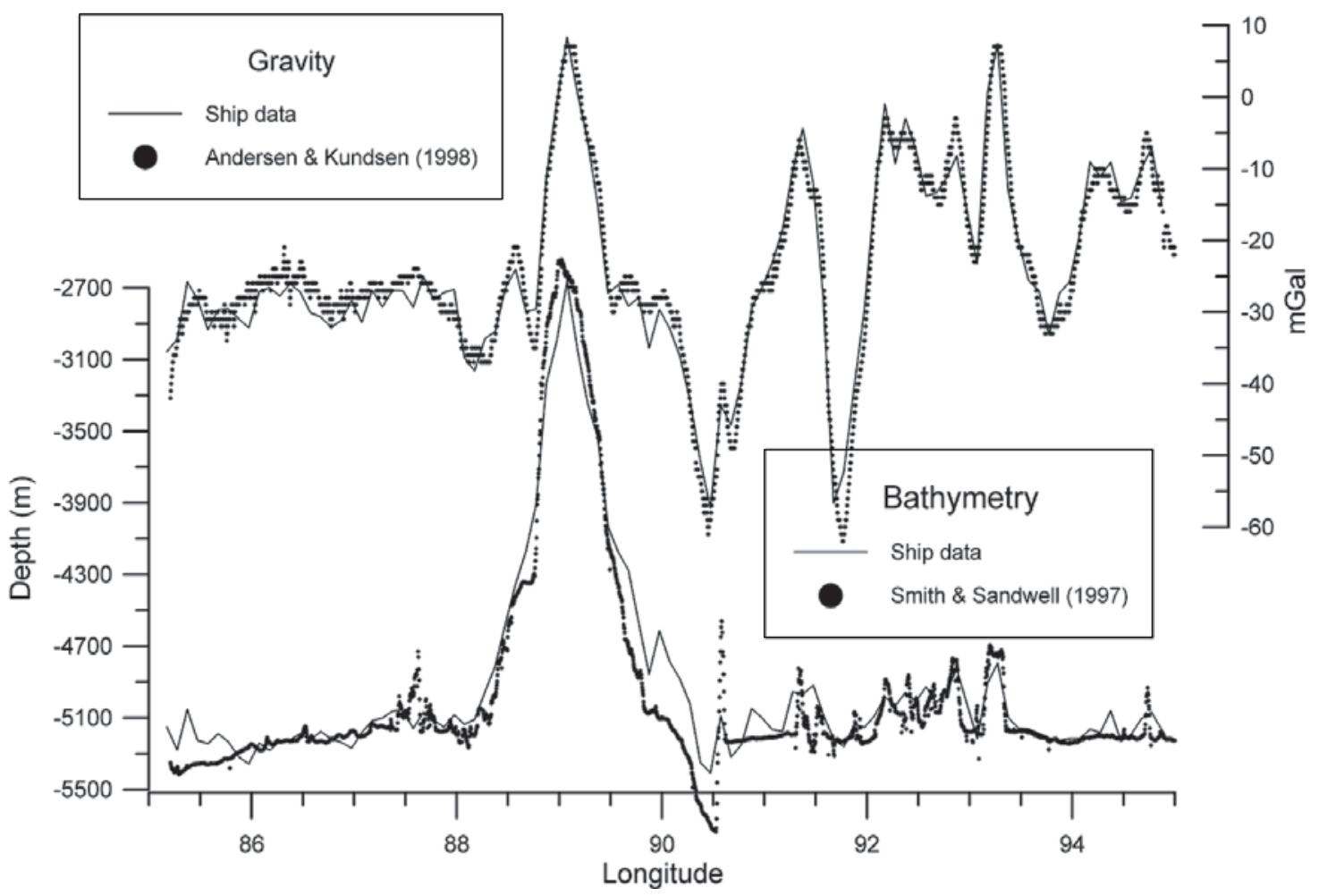

b)
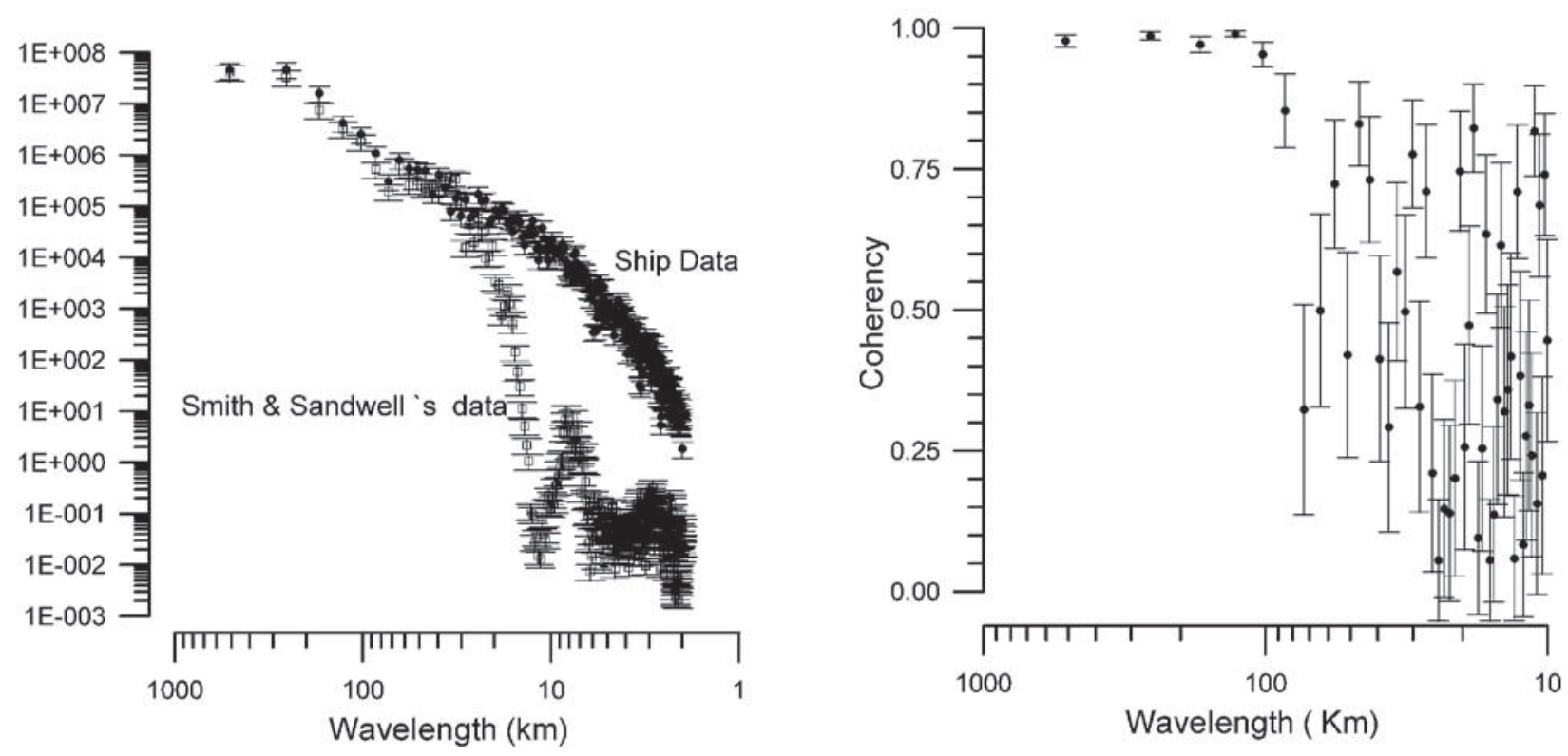

Figure 3. (a) Ship-borne gravity and bathymetry data along with satellite-derived gravity [Andersen and Knudsen, 1998] and bathymetry [Smith and Sandwell, 1997] are plotted for comparison along a profile following $7.5^{\circ}$ latitude, which cuts the Ninety-East Ridge. (b) Comparison of power spectrum of ship-borne bathymetry and bathymetry from Smith and Sandwell [1997], along a profile following $7.5^{\circ}$ latitude and coherency between them.

are derived from gravity data and adjusted to coincide with ship-borne bathymetric points therefore precaution should be taken, while using these data for the analyses.

[5] Satellite-derived gravity data (Figure 4) [Andersen and Knudsen, 1998] shows a high free-air anomaly asso- ciated to NER. However, the observed gravity high is much smaller than the gravity effect of the bathymetry, which suggests that the ridge is compensated at depth [Bowin, 1973; Detrick and Watts, 1989; Hébert et al., 1996]. In the southern latitudes the gradient of gravity anomaly is much 


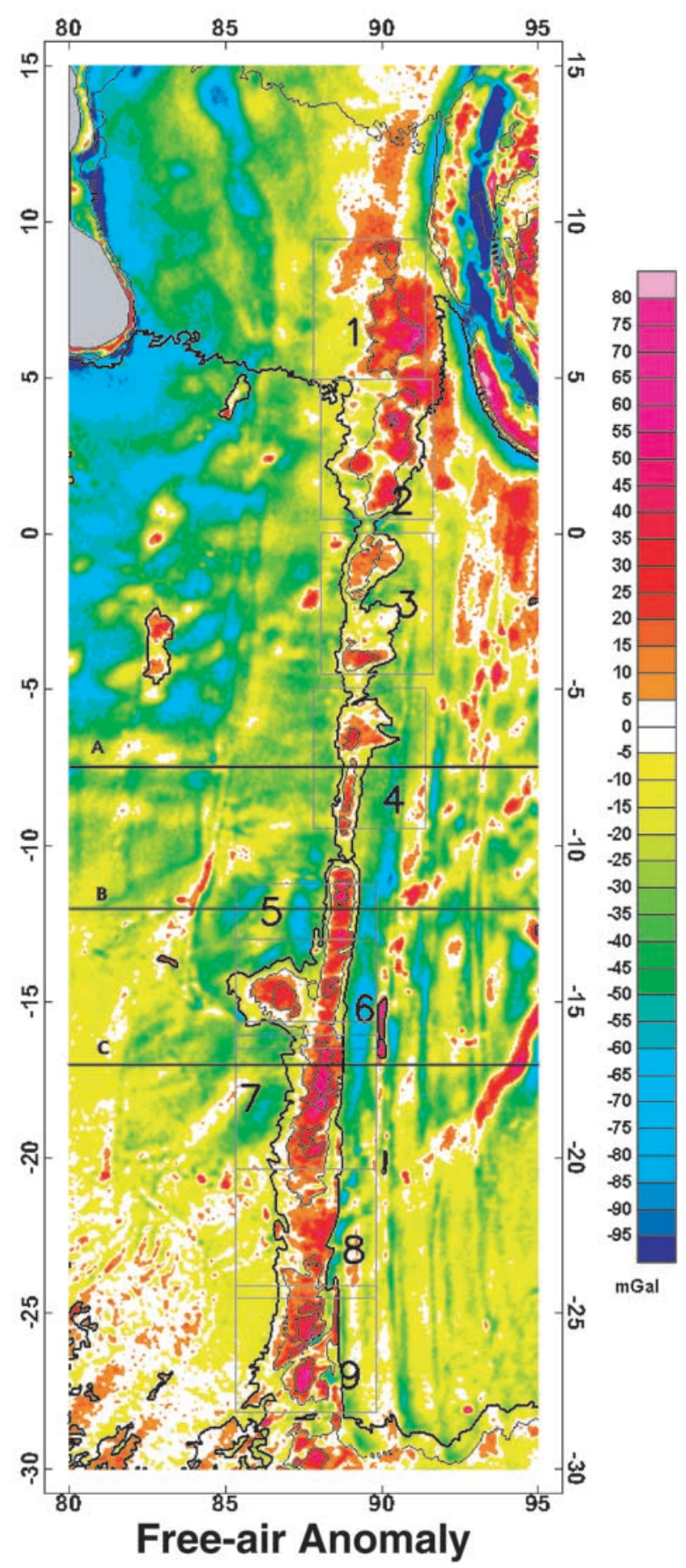

Figure 4. Satellite-derived free -air anomaly map of the surrounding area of Ninety-East Ridge [Andersen and Knudsen, 1998]. Bathymetric contours of 4000, 3000, and $2000 \mathrm{~m}$ are also drawn using gridded bathymetry from Smith and Sandwell [1997]. Lines are the profiles used for direct modeling, and violet rectangles outline the regions used for spectral analysis.

higher on the eastern flank of NER than along the western flank, which suggests the presence of sharp density contrasts from geological structure such as fracture zones or faults. There is a linear gravity anomaly parallel to the ridge in the east of NER. Many NE-SW trending anomalies associated with bathymetry intersect this anomaly. Such features are almost absent in the west of the NER. This shows that the ridge separates oceanic structure of two different kinds in these southern latitudes. The fold belt in the east and the Bengal Fan sediments in the west are the most prominent features in the north.

\subsection{Isostatic Anomaly Map}

[6] Satellite-derived data have uniform coverage and comparable amplitude and pattern to the sea surface data for wavelengths larger than $100 \mathrm{~km}$, the diagnostic wave band for isostatic analyses. Therefore they can be used to study isostasy of a particular region and to infer broad density anomalies. For example, satellite data provided similar result as the one deduced from ship-borne data over the Hawaiian chain [McKenzie and Fairhead, 1997]. Satellite-derived data were also used to infer the compensation mechanism in the areas that are poorly covered by sea surface data (e.g., on Ontong Java plateau by Ito and Taira [2000] and on Louisville Ridge by Lyons et al. [2000]).

[7] Earlier studies of isostasy [Detrick and Watts, 1989; Hébert et al., 1996] have suggested local compensation for the NER. Departure from local compensation can be seen from isostatic anomaly map. We have computed Airy isostatic anomalies (Figure 5) by subtracting the gravity effect of bathymetry and a crustal root from satellite-derived free-air anomaly [Andersen and Knudsen, 1998] using the Parker's [1972] series up to degree 4 to take into the account of the nonlinear effects [e.g., Lyons et al., 2000]. The Moho depth was fixed to $12 \mathrm{~km}$ according to seismic results [Francis and Raitt, 1967; Grevemeyer et al., 2001], i.e., a crustal thickness of $\sim 7 \mathrm{~km}$ (or Moho depth at $12 \mathrm{~km}$ from sea level) on either side of the NER. The density contrasts between basement and water and between mantle and crust are assumed as 1470 and $400 \mathrm{~kg} \mathrm{~m}^{-3}$, respectively. Figure 5 shows large isostatic anomalies and indicates that either there is a departure from the above considered model or an existence of other sources of gravity anomaly not related to topography and its compensation.

\subsection{Modeling Along Profiles}

[8] To investigate the gravity anomaly related to topography and its compensation, we first used forward modeling along three long profiles $(\sim 1500 \mathrm{~km})$ selected across NER in the area of thin sedimentary strata. The first profile is along the ship track that follows $7.5^{\circ} \mathrm{S}$ latitude [Hébert et al., 1996]. The second profile follows a wideangle seismic profile at $17^{\circ} \mathrm{S}$, close to Osborn Knoll [Grevemeyer et al., 2001]. Third profile is taken in between these two profiles, along $12^{\circ} \mathrm{S}$ latitude. The gravity effects of bathymetry and its compensation at 12 $\mathrm{km}$ depth are computed along these profiles assuming an elastic plate model for different values of effective elastic thickness (EET) and best visual fits are considered for comparison. The compensation depth of $12 \mathrm{~km}$ is chosen on the basis of seismic results [Francis and Raitt, 1967; Grevemeyer et al., 2001]. As is apparent from Figures 6a and $6 \mathrm{~b}$, the observed values along profiles 1 and 2 are close to the gravity effect computed for EET $=0$ over the NER. An EET $=10 \mathrm{~km}$ compares better with the observed data along profile 3 with misfit $(>10 \mathrm{mGal})$ at some places 


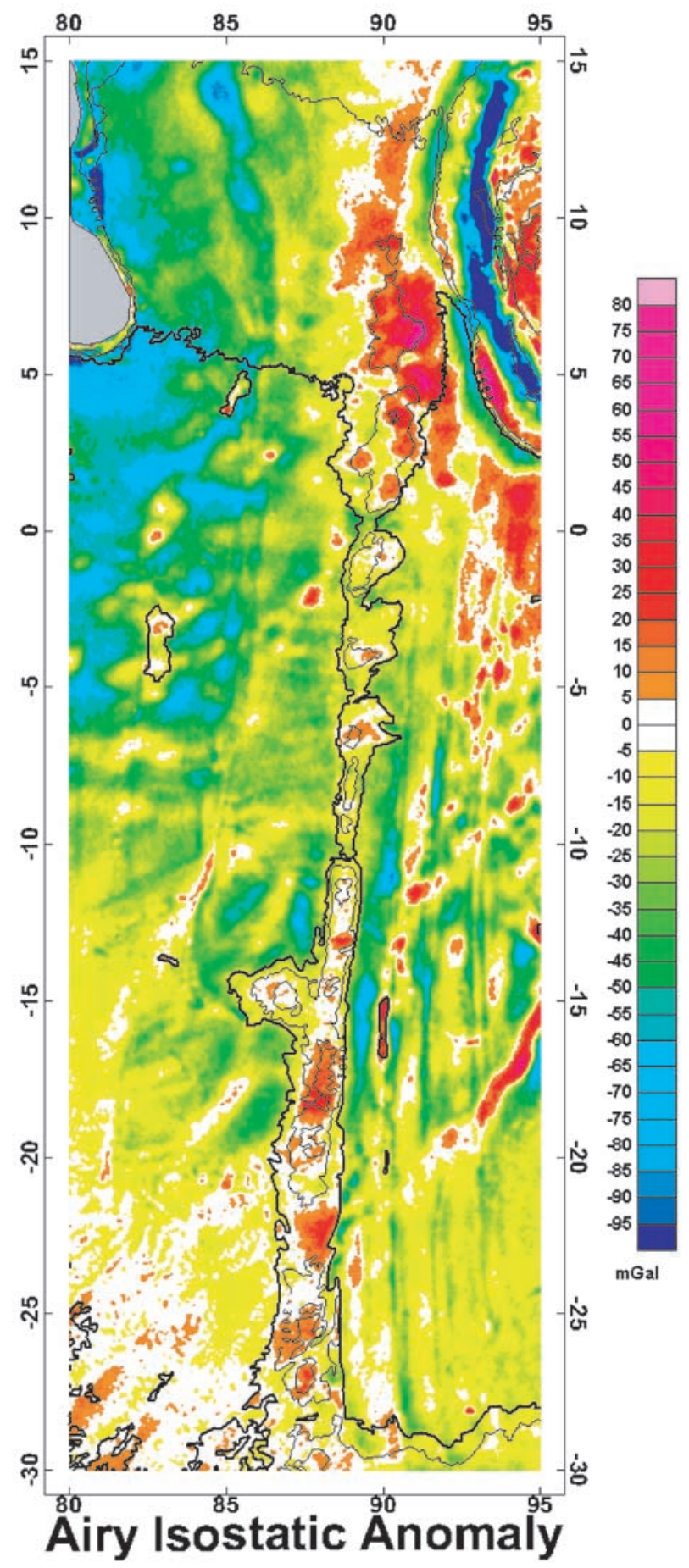

Figure 5. Airy isostatic anomaly map of the surrounding area of Ninety-East Ridge generated by removing gravity effect of topography and its root (Airy) from the satellitederived free-air anomaly [Andersen and Knudsen, 1998]. Bathymetric contours of 4000, 3000, and $2000 \mathrm{~m}$ are also drawn using gridded bathymetry from Smith and Sandwell [1997].

(Figure 6c). However, Moho depth predicted for EET $=10$ $\mathrm{km}$ is $\sim 20 \mathrm{~km}$ compared to $\sim 25 \mathrm{~km}$ reported from seismic result [Grevemeyer et al., 2001]. Even EET $=0 \mathrm{~km}$, which means local compensation does not yield as large Moho depth as the one reported from seismic results. This suggests that the density contrast at the crust-mantle boundary should be less than the one assumed $(400 \mathrm{~kg}$ $\mathrm{m}^{-3}$ ) for modeling. Reducing the density of upper mantle or increasing the density of lower crust or a combination of both can either reduce the density contrast at Moho. The high lower crustal velocity reported along this profile [Grevemeyer et al., 2001] indicates increase of lower crustal density which in turn will produce a positive gravity effect and eventually lead to a greater misfit for EET $=10 \mathrm{~km}$. The observed data thus can only be explained with very small EET, close to zero. Modeling along these profiles also shows the gravity lows near $92^{\circ} \mathrm{E}$ along profile 1 (Figure $6 \mathrm{a}$ ) and $85^{\circ} \mathrm{E}$ along profiles 2 and 3 (Figures $6 \mathrm{~b}$ and $6 \mathrm{c}$ ) that cannot be explained with any isostatic model and requires large sediment thickness $(\sim 1$ $\mathrm{km})$ for its explanation, which is unlikely. Moreover, gravity low observed along profile 1 is also reported from detailed shallow seismic and shipborne gravity studies [Hébert, 1998]. This gravity low corresponds to a fossil spreading center and an associated transform fault [Hébert, 1998] and could be caused by a crustal thickening as proposed by Hébert [1998] or be due to an upper mantle density inhomogeneities.

\subsection{Analysis in the Frequency Domain}

[9] In order to further investigate possible variation in the deep density structure and the state of isostasy, we have analyzed data over separate rectangular blocks (Figure 4). Information about approximate depth of the major causative source of gravity anomaly is obtained using the power spectrum of gravity [Spector and Grant, 1970] for these blocks (Figure 7 and Table 1). The depth range is quite high for some blocks and may not be representative of actual depth, as this method often tends to over estimate the depth [Hahn et al., 1976]. The uncertainty in the computed depth is estimated from the range of the slope of the best fit line by varying the wave band width used for the fit (Figure 7). The seismic study near $17^{\circ} \mathrm{S}$ latitude provides a crustal thickness of $25 \mathrm{~km}$ under NER and $7 \mathrm{~km}$ on either side. A subcrustal velocity interface $(8.2-8.4 \mathrm{~km}$ $\mathrm{s}^{-1}$ ) below NER is also reported at $\sim 35 \mathrm{~km}$ [Grevemeyer et al., 2001]. The average deepest density interface from spectral estimate for a block encompassing the area of the seismic experiment $\left(16^{\circ}-20^{\circ} \mathrm{S}\right)$ is $42 \pm 5 \mathrm{~km}$, which may be an overestimate of seismic interface. Hence the depths we obtained from spectrum of gravity data seem to be realistic and indicate the deepest density interfaces, which could be Moho in some cases.

[10] To further analyze the relationship of the gravity anomaly to topography, we computed the admittance, the ratio of gravity anomaly to topography as a function of wavelength over the same nine blocks previously used. Admittance technique has been widely used in oceanic domain to determine EET [e.g., McKenzie and Bowin, 1976; Watts, 1978; Cochran, 1979; Louden and Forsyth, 1982]. Bias in the estimate of EET determined from this technique is now well known [Macario et al., 1995], especially in continental domain if subsurface loading is present [Forsyth, 1985] or in oceanic domain due to the fact that only first term in Parker's series is taken into account [Lyons et al., 2000]. However, experimental admittances (and coherences) analyses provide indication 

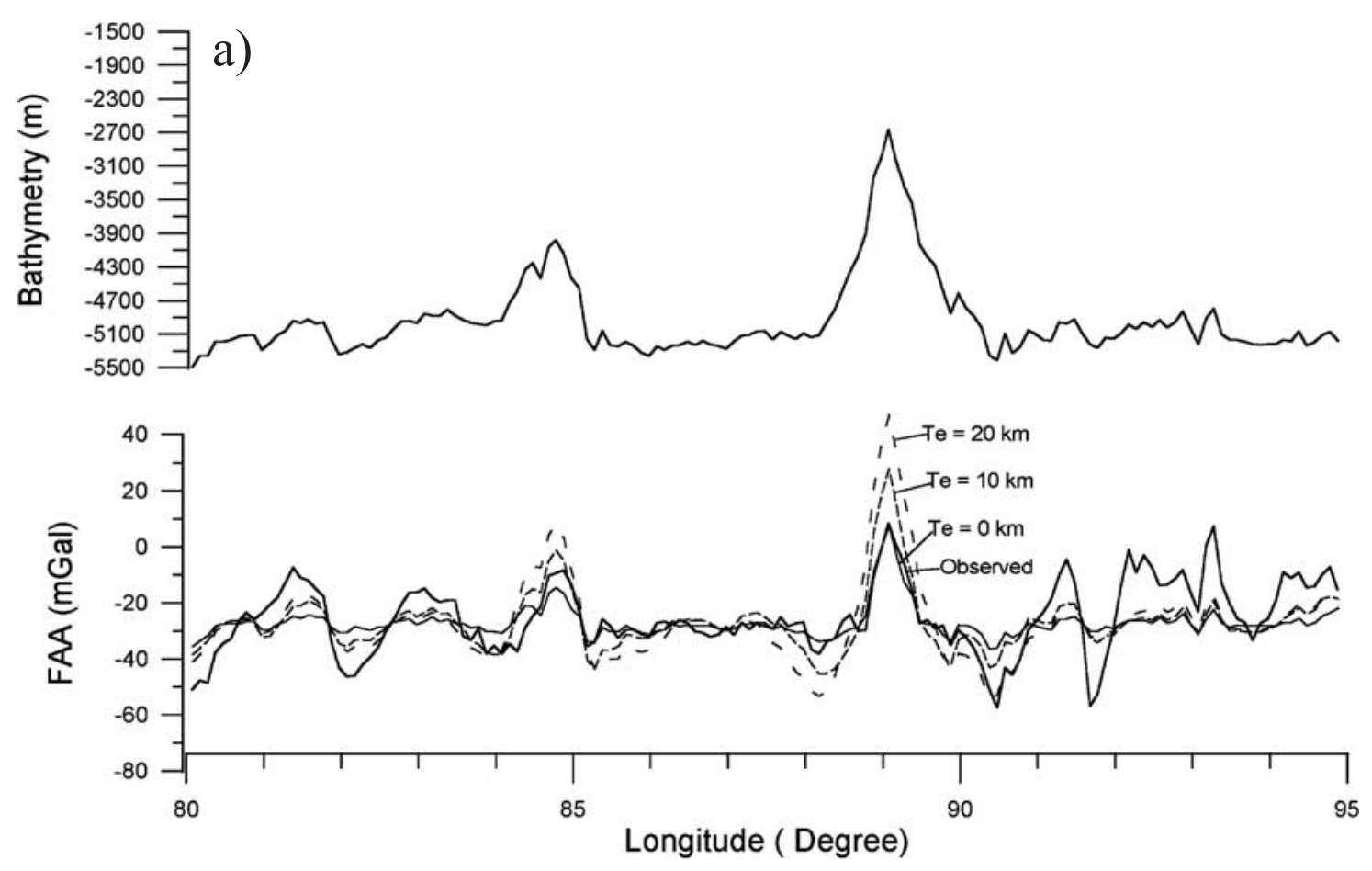

Figure 6. (a) Free-air anomaly and bathymetry along a ship track following $7.5^{\circ} \mathrm{S}$ latitude plotted in gray. Gravity effect of bathymetry and its compensation for the plate thickness of $0 \mathrm{~km}$ (solid line), $10 \mathrm{~km}$ (short dashed line) and $20 \mathrm{~km}$ (long dashed line) are also shown. (b) Plots along a profile following $12^{\circ} \mathrm{S}$ latitude other details are same as in Figure 6a. (c) Plots along a profile following $17^{\circ} \mathrm{S}$ latitude other details are same as in Figure 6a.

on the isostatic behavior without any a priori assumption and thus can be a very powerful approach to study possible variations in the EET along the NER. Admittance is expressed as

$$
Z(k)=\frac{\left\langle G B^{*}\right\rangle}{\left\langle B B^{*}\right\rangle}
$$

where $G$ and $B$ are Fourier transforms of gravity and bathymetry, asterisks denote complex conjugate, and angle brackets denote the average value over a wave band centered on a wave number $(k)$.

[11] This approach assumes a laterally homogenous plate, yet analyses in the earlier section suggest probably lateral variations in the density structure and EET. Considering this, we have selected our grids such that they fall over NER and few tens of kilometers on either side. We used a 3-D approach to compute admittance for gridded gravity and bathymetry data. The gridded data sets were mirrored before Fourier transform, and an averaging was done over annuli. We computed the admittances using different global data sets such as ETOPO5, Terrain base (5 minute grid) [National Geophysical Data Center (NGDC), 1988], which have bathymetry from interpolation of only ship data. In areas reasonably covered with ship tracks, different data sets give similar values at large wavelengths. However, as could be expected, there are considerable discrepancies between admittances computed with different data sets in the poorly surveyed areas by oceanographic cruises (south of $25^{\circ}$ latitude in our study area) even for large wavelengths. However, we obtained similar admittance values using global data sets (present study) and as one computed using ship-borne bathymetry [Grevemeyer and Flueh, 2000] even in the poorly surveyed areas. Therefore we have used bathymetric grid by Smith and Sandwell [1997], which has an advantage of having uniform coverage.

[12] Two models were considered for the computation of theoretical admittance: model 1, plate model loaded on top [e.g., McKenzie and Bowin, 1976]; and model 2, a model in which plate is loaded on both the top and bottom [Forsyth, 1985; McAdoo and Sandwell, 1989]. These models can provide information on subsurface loading as underplating is suggested by seismic results [Grevemeyer et al., 2001]. Theoretical equations of admittance have been followed from McAdoo and Sandwell [1989] and expressed below:

Surface loading

$$
Z_{t}(k)=Z_{0}(k)\left(1-\frac{e^{-k h}}{\xi}\right)
$$

where

$$
\begin{gathered}
\left.Z_{0}(k)=2 \Pi G \rho_{c 1}-\rho_{w}\right) e^{-k d}, \\
\xi=1+\frac{D k^{4}}{g\left(\rho_{m}-\rho_{c 2}\right),} \\
D=\frac{E T_{e}^{3}}{12\left(1-\sigma^{2}\right)},
\end{gathered}
$$



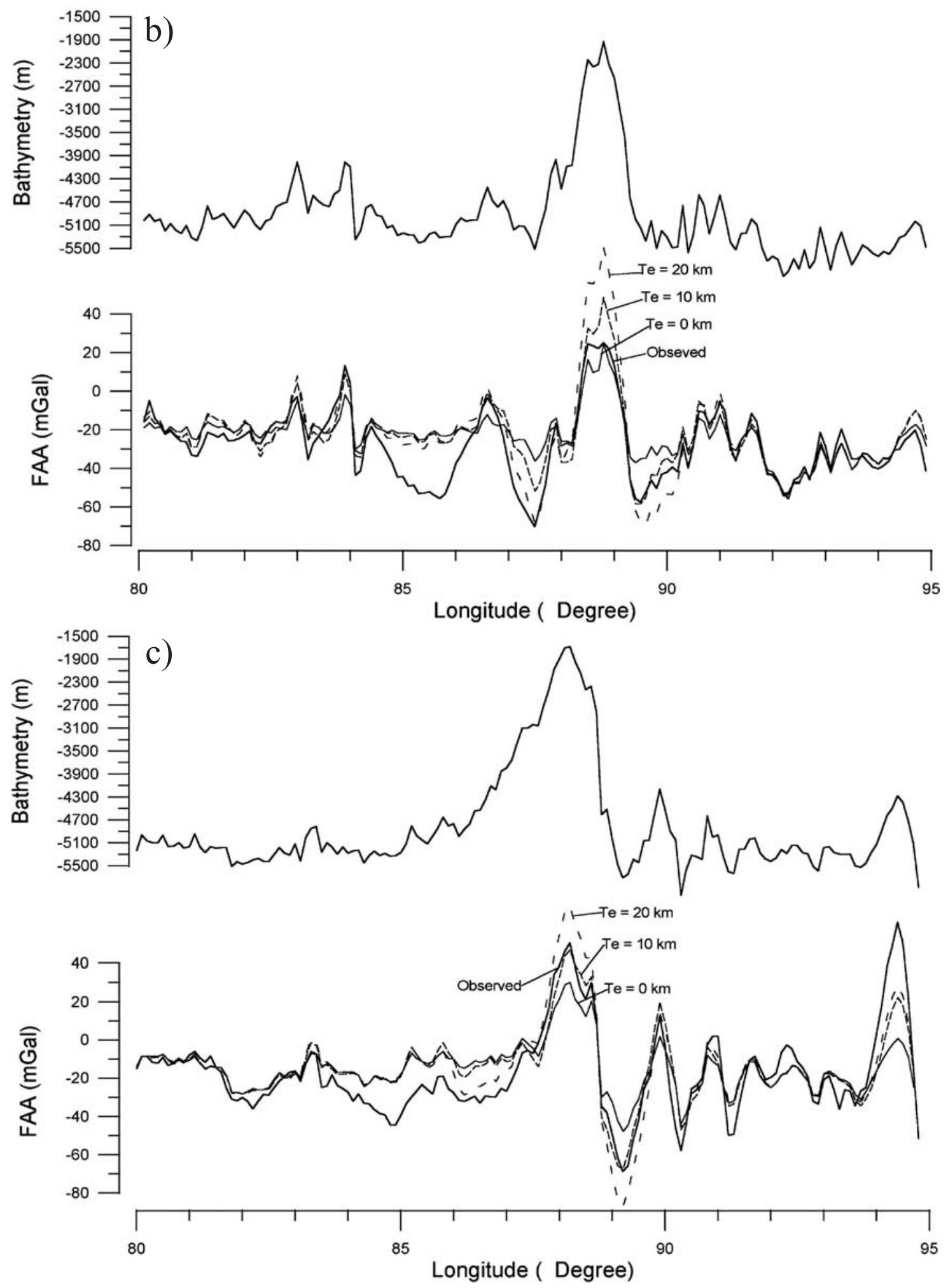

Figure 6. (continued)

$h$ is crustal thickness, and $d$ is average depth.

where

Subsurface loading

$$
Z_{b}(k)=Z_{0}(k)\left[1+\left(\frac{\rho_{m}-\rho_{c 3}}{\rho_{c 3}-\rho_{w}}\right) e^{-k h}-\left(\phi \frac{\rho_{m}-\rho_{w}}{\rho_{c 3}-\rho_{w}}\right) e^{-k z},\right.
$$

$$
\phi=1+\frac{D k^{4}}{g\left(\rho_{m}-\rho_{w}\right)}
$$




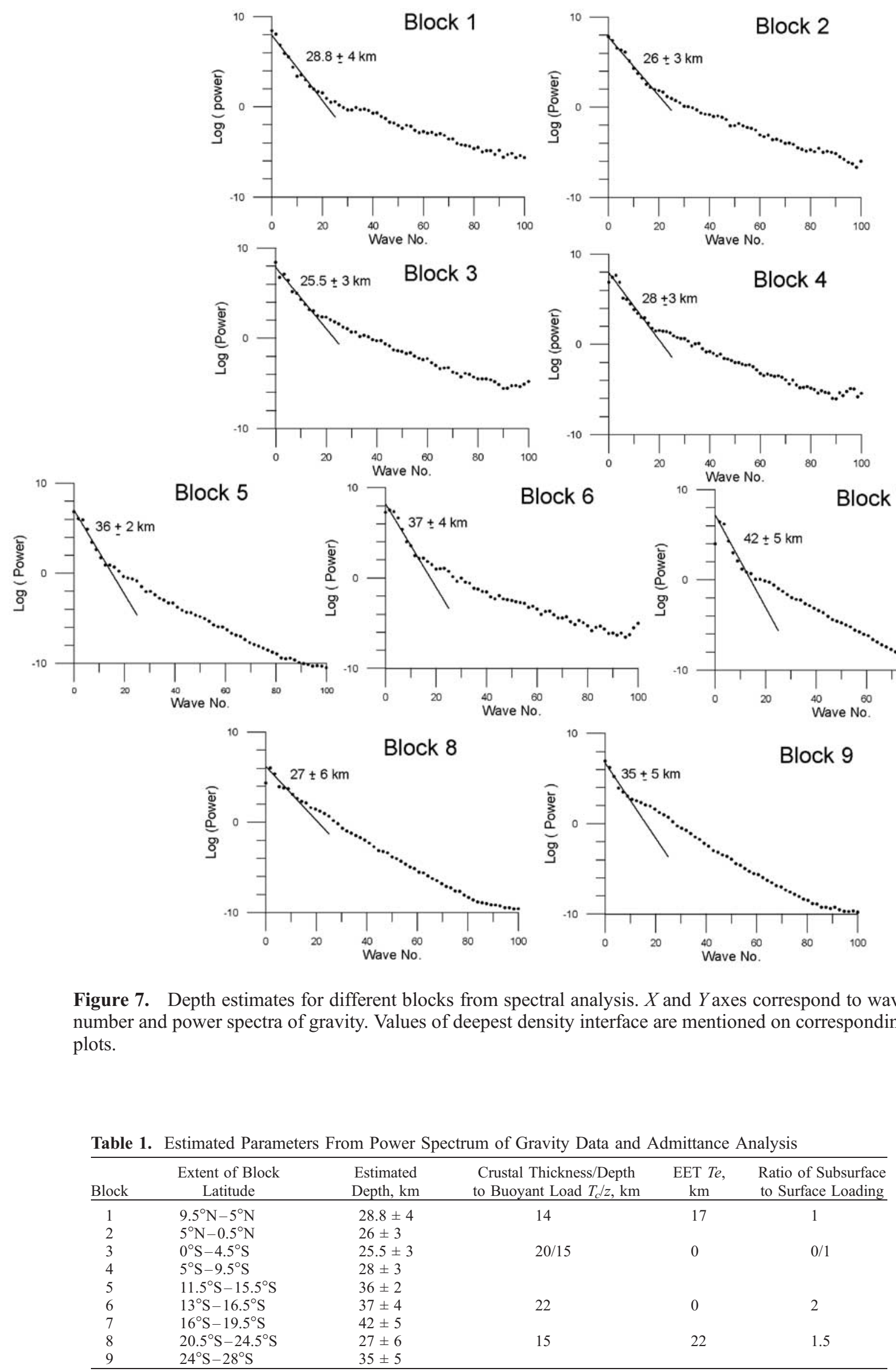


Table 2. Parameters Used in Admittance Analysis

\begin{tabular}{ll}
\hline \multicolumn{1}{c}{ Parameter } & \multicolumn{1}{c}{ Value } \\
\hline$G$, gravitational constant & $6.67 \times 10^{-8} \mathrm{~N} \mathrm{~m}^{2} \mathrm{~kg}^{-2}$ \\
$E$, Young's modulus & $10^{11} \mathrm{~N} \mathrm{~m}^{-2}$ \\
$\sigma$, Poisson ratio & 0.25 \\
$\rho_{c 1}-\rho_{w}$, density contrast between basement and of seawater & $1470 \mathrm{~kg} \mathrm{~m}^{-3}$ \\
$\rho_{m}-\rho_{c 2}$, density contrast between upper mantle and lower crust & $400 \mathrm{~kg} \mathrm{~m}^{-3}$ \\
$\rho_{m}-\rho_{c 3}$, density contrast between upper mantle and lower crust & $200 \mathrm{~kg} \mathrm{~m}^{-3}$ \\
$\quad$ & \\
$\rho_{m}-\rho_{w}$, density contrast between upper mantle and seawater & $2270 \mathrm{~kg} \mathrm{~m}^{-3}$ \\
$g$, acceleration due to gravity & $9.8 \mathrm{~m} \mathrm{~s}^{-2}$ \\
\hline
\end{tabular}

Combined loading: surface and subsurface

$$
Z_{c}(k)=\left[\frac{\beta^{2} Z_{b}(k)+Z_{t}(k)}{\beta^{2}+1}\right],
$$

where

$$
\beta=f\left[\frac{\rho_{c}-\rho_{w}}{\rho_{m}-\rho_{c}+D k^{4} / g}\right]
$$

$h$ is crustal thickness, $z$ is the depth to the buoyant load in the case of subsurface loading, and $f$ is the ratio of subsurface to surface loading. Other parameters are defined in the Table 2.

[13] Calculated admittance for each block with standard error bars and theoretical admittance are plotted in the Figures $8-11$. The decrease in the amplitude of admittance at long wavelengths (wave number $>0.3 \mathrm{~km}^{-1}$ or wavelength $>150 \mathrm{~km}$ ) for all blocks reflects that isostatic compensation prevail all over NER. However, the rate of change in the amplitude of admittance is different for different blocks indicating the differences in the compensation mechanism. This can be investigated by comparing the computed admittance to the theoretical curves calculated for the above mentioned models. Admittances for blocks of similar nature are plotted in the same figure and only one best fit curve is plotted as a representative for them. On the various possibility of fitting the observed admittance, we chose best amongst all reasonably visual fits by taking into account of additional information such as seismic results and tectonics.

[14] The plate model with both surface and subsurface loading can fit the observed admittance values from the northern part (blocks 1 and 2) of the NER (Figure 8). The parameters obtained are EET $=17 \mathrm{~km}, z=14 \mathrm{~km}$, and $f=1$. The value of $z$ is in good agreement with the depth obtained from the interpretation of gravity spectrum. The gradual decrease in admittance for the block 3 (Figure 9) can only be explained assuming a very low rigidity. A nonrigid plate, i.e., an Airy model with crustal thickness $20 \mathrm{~km}$ yields a good fit. Crustal thickness is high but is in the range of crustal thickness observed under aseismic ridges worldwide $(15-25 \mathrm{~km})$ [e.g., Detrick and Watts, 1979]. A model of surface and subsurface loading can explain observed admittance with a slightly smaller thickness but the value of EET would remain low (Figure 9). Thus we favor local compensation for this area, which is in agreement with the result of our direct modeling along ship track, following $7.5^{\circ} \mathrm{S}$ latitude (Figure 6a). The computed admittance for blocks $(5,6$, and 7$)$ at large wavelengths decreases very slowly and can be explained by an Airy model with a crustal thickness of $>30 \mathrm{~km}$, which is unreasonably large (Figure 10). Computed admittances values for these blocks are smaller than the theoretical values for the plate model. Since our preliminary direct modeling in this area yielded an EET of $\sim 10 \mathrm{~km}$, we have investigated other combinations of theoretical admittance assuming EET $=10 \mathrm{~km}$, by varying the values of subsurface to surface loading and depth to the buoyant load. However, none of the models satisfactorily explains the values of the observed admittances. The effect of subsurface loading reduces admittance values at larger wavelength but also produces negative admittance, which is not at all observed. In this area, Grevemeyer and Flueh [2000] explained the observed admittances with a model of $z=$ $25 \mathrm{~km}, f=1$ and EET $=5 \mathrm{~km}$ (Figure 10). They have preferred $z=25 \mathrm{~km}$ on the basis of observed seismic crustal thickness of $25 \mathrm{~km}$ [Grevemeyer et al., 2001]. We prefer a model with surface and subsurface loading $(f=2)$, depth to the buoyant load $(z)$ as $22 \mathrm{~km}$ and EET $=0 \mathrm{~km}$ (local compensation). We prefer it because crustal thickness obtained from isostatic studies is always less than actual crustal thickness [Detrick and Watts, 1979; McAdoo and Sandwell, 1989] and the center of the buoyant subsurface mass is comparable to the Moho depth [McAdoo and Sandwell, 1989], except in areas of dynamic compensation [e.g., McNutt and Shure, 1986]. Nevertheless, whichever model one prefers, the value of EET remains low (close to zero). Finally, the admittances of southern blocks are little scattered and one of them shows negative value suggesting subsurface loading on a plate of finite strength (Figure 11). This observation suggests that a most likely model will be a plate model with sub surface loading. A good fit curve is obtained for EET $=22 \mathrm{~km}$. Parameters obtained from admittance analysis, forward modeling along profiles and spectral depth estimates obtained from power spectrum are given in the Table 1 and comparable to each other. For example, we obtained $\sim 20 \mathrm{~km}$ crustal thickness for blocks 3 and 4 from admittance analysis, $\sim 22 \mathrm{~km}$ Moho depth from modeling of profile A and depth of causative sources $25 \pm 3$ for block $3,28 \pm 3 \mathrm{~km}$ for block 4 from power spectrum. These results are in good agreement.

\section{Discussion and Conclusions \\ 3.1. Mode of Compensation of NER and Tectonic Implication}

[15] Substantial differences in the isostatic response of the different parts of NER have been evidenced in section 

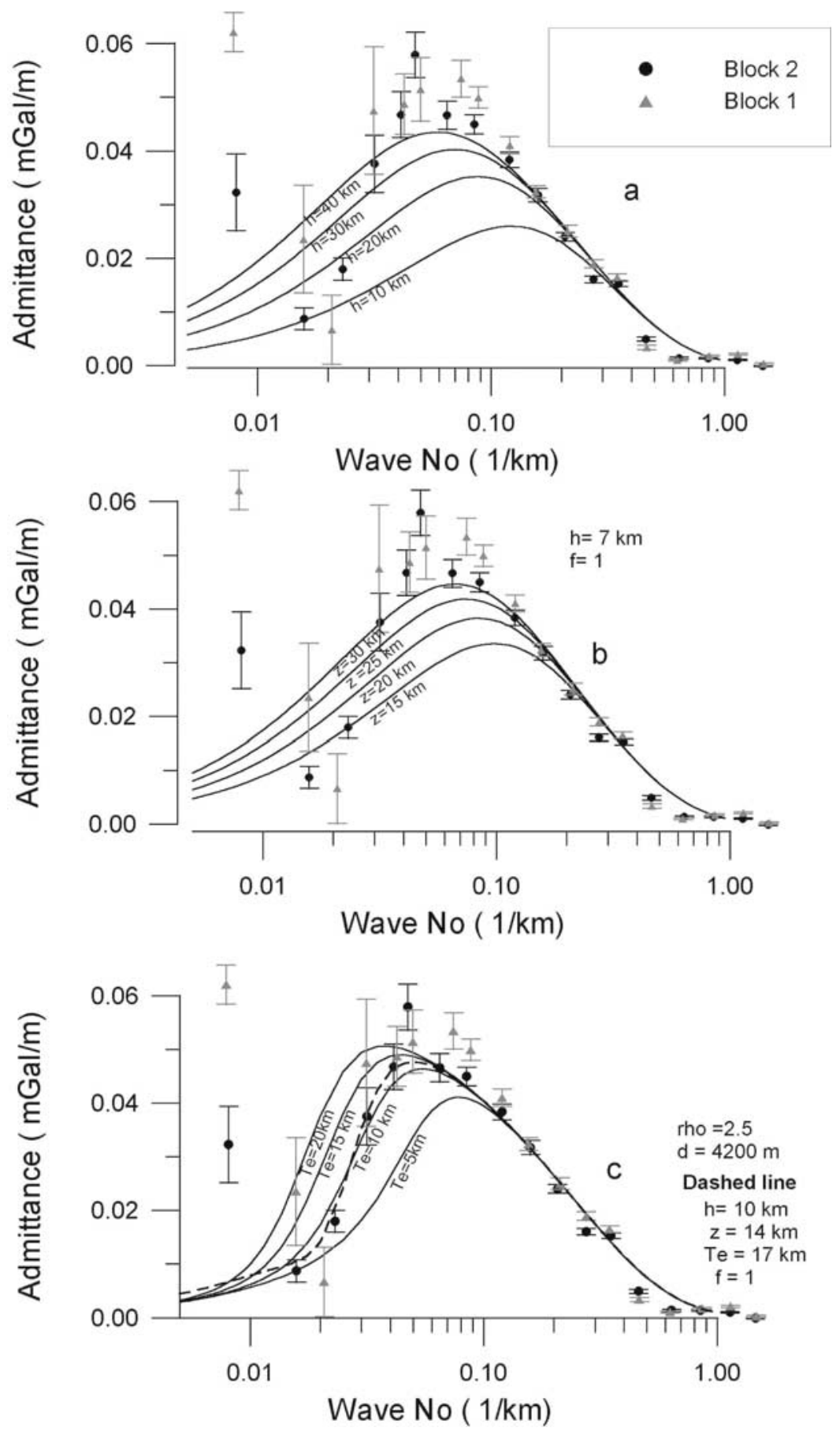

Figure 8. (a) Plots of theoretical admittance based on AIRY model for various crustal thickness $(h)$. Computed admittance values for block 1 (solid rectangles) and block 2 (solid dots) with standard error bar are also plotted. Other parameters are written to the corresponding plots. (b) Plots of theoretical admittance for various compensating depths and zero plate thickness (Te) based on plate model of equal ratio of surface to subsurface loading $(f=1)$. Other details are as in Figure 8a. (c) Plots of theoretical admittance for various thickness of plate and crustal thickness of $10 \mathrm{~km}$ based on plate model of surface loading only. Best fit (block dashed line) represents theoretical admittance for $T e=17 \mathrm{~km}$, compensating depth $(z)=14 \mathrm{~km}$ and equal surface to subsurface loading $(f=1)$. Other details are as in Figure 8a.

2.3. Our results in general agree with earlier results [e.g., Detrick and Watts, 1979; Grevemeyer and Flueh, 2000] for those parts of the NER where gravity and bathymetry data have been analyzed previously, and in addition, they provide new information about compensation from other parts of the NER. The northern block $\left(0-10^{\circ} \mathrm{N}\right)$ and the southern block $\left(20-30^{\circ} \mathrm{S}\right)$ are flexurally compensated with an effective elastic thickness $>15 \mathrm{~km}$, whereas the central block $\left(0-20^{\circ} \mathrm{S}\right)$ is locally compensated. The inferred value of EET $>15 \mathrm{~km}$ for the northern and 

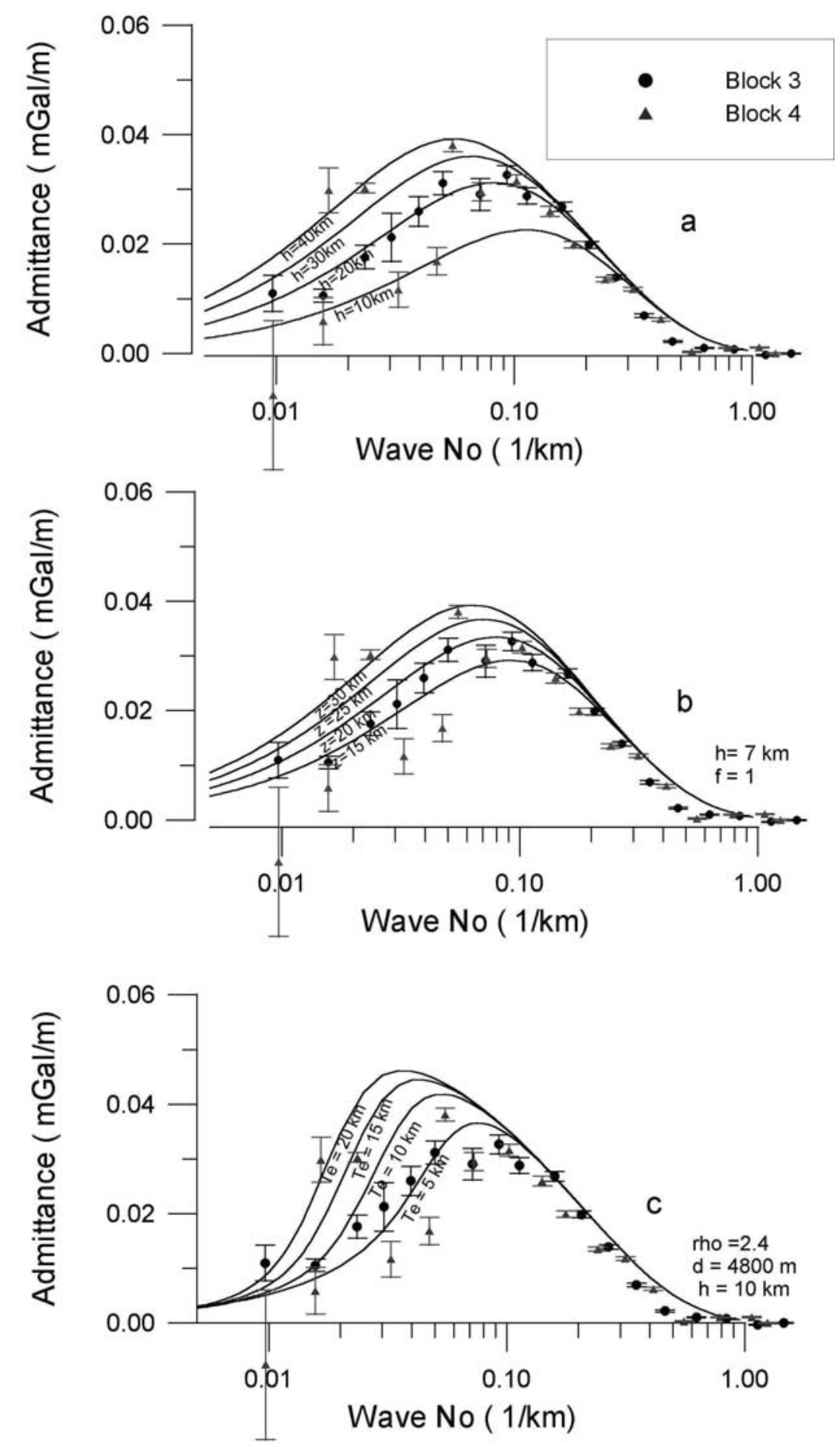

Figure 9. (a) Plots of theoretical admittance based on AIRY model for various crustal thicknesses $(h)$. Computed admittance values for block 3 (solid dots) and block 4 (solid rectangles) with standard error bars are also plotted. Airy model better predicts computed admittance. Other parameters are written to the corresponding plots. (b) Plots of theoretical admittance for various compensating depths and zero plate thickness $(T e)$ based on plate model of equal ratio of surface to subsurface loading $(f=1)$. Other details are as in Figure 9a. (c) Plots of theoretical admittance for various thickness of plate and crustal thickness (h) of $10 \mathrm{~km}$ based on plate model of surface loading only. Other details are as in Figure 9a.

southern part of NER suggests an off-ridge (i.e., off from spreading center) emplacement. Assuming that there was no significant thermal rejuvenation [Crough, 1983], this value of EET will suggest a 20-m.y.-old lithosphere at the time of loading [Watts et al., 1980; Watts and Zhong,
2000]. Our contention also finds support from the results of analysis of subsidence history of drilling site 216, located in the northern part of NER that the basement at this site was supported either by thermal or mechanical forces for $\sim 11$ m.y. [Coffin, 1992]. This agrees with a 

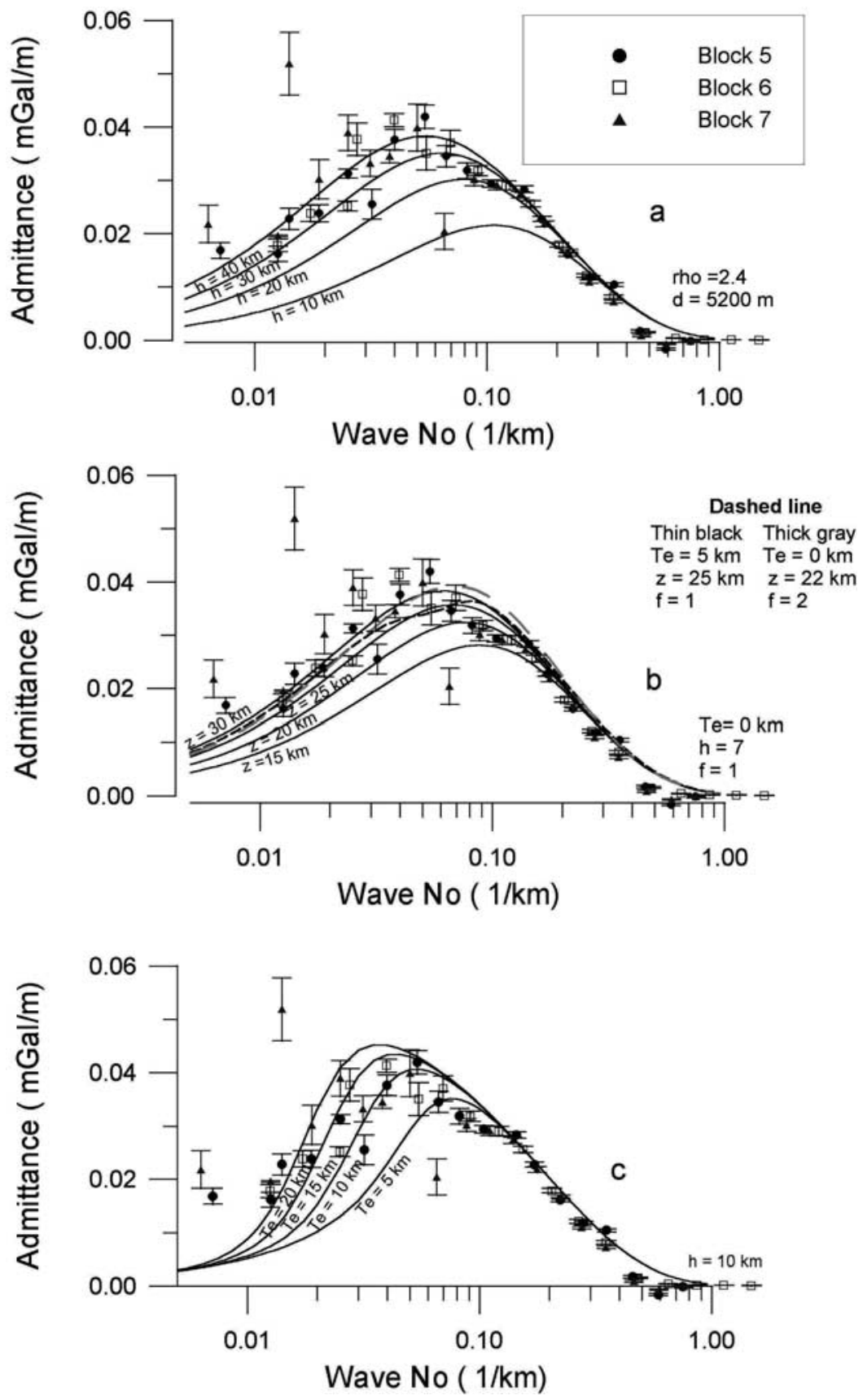

Figure 10. (a) Plots of theoretical admittance based on AIRY model for various crustal thicknesses $(h)$. Computed admittance values for block 5 (solid rectangles) and block 6 (solid dots) with standard error bar are also plotted. Other parameters are written to the corresponding plots. (b) Plots of theoretical admittance for various compensating depths $(z)$ and zero plate thickness $(T e)$ based on plate model of equal ratio of surface to subsurface loading $(f=1)$. Dashed line is best fit which represents compensating depth of $22 \mathrm{~km}$ with $f=2$ and $T e=0$. Small dashed line shows $T e=5 \mathrm{~km}, f=1$, and compensating depth of $25 \mathrm{~km}$. Both dashed lines equally fit the computed admittance. Other details are as in Figure 10a. (c) Plots of theoretical admittance for various thickness of plate and crustal thickness of $10 \mathrm{~km}$ based on plate model of surface loading only. Other details are as in Figure 10a.

flexural compensation model deduced in this study. The low value of EET or local compensation for central part may suggest that this part of NER was emplaced onridge, i.e., very close to a spreading center. The differences in the ages of the rocks from NER and ages deduced from magnetic anomalies are more or less com- parable to each other. However, incompatibility could arise due to less constrained magnetic anomalies in the vicinity of NER (Figure 2). Variations in the isostatic response we evidence along the NER support a model of emplacement of the NER similar to the one proposed by Royer et al. [1991]: Intraplate volcanism on the Indian 

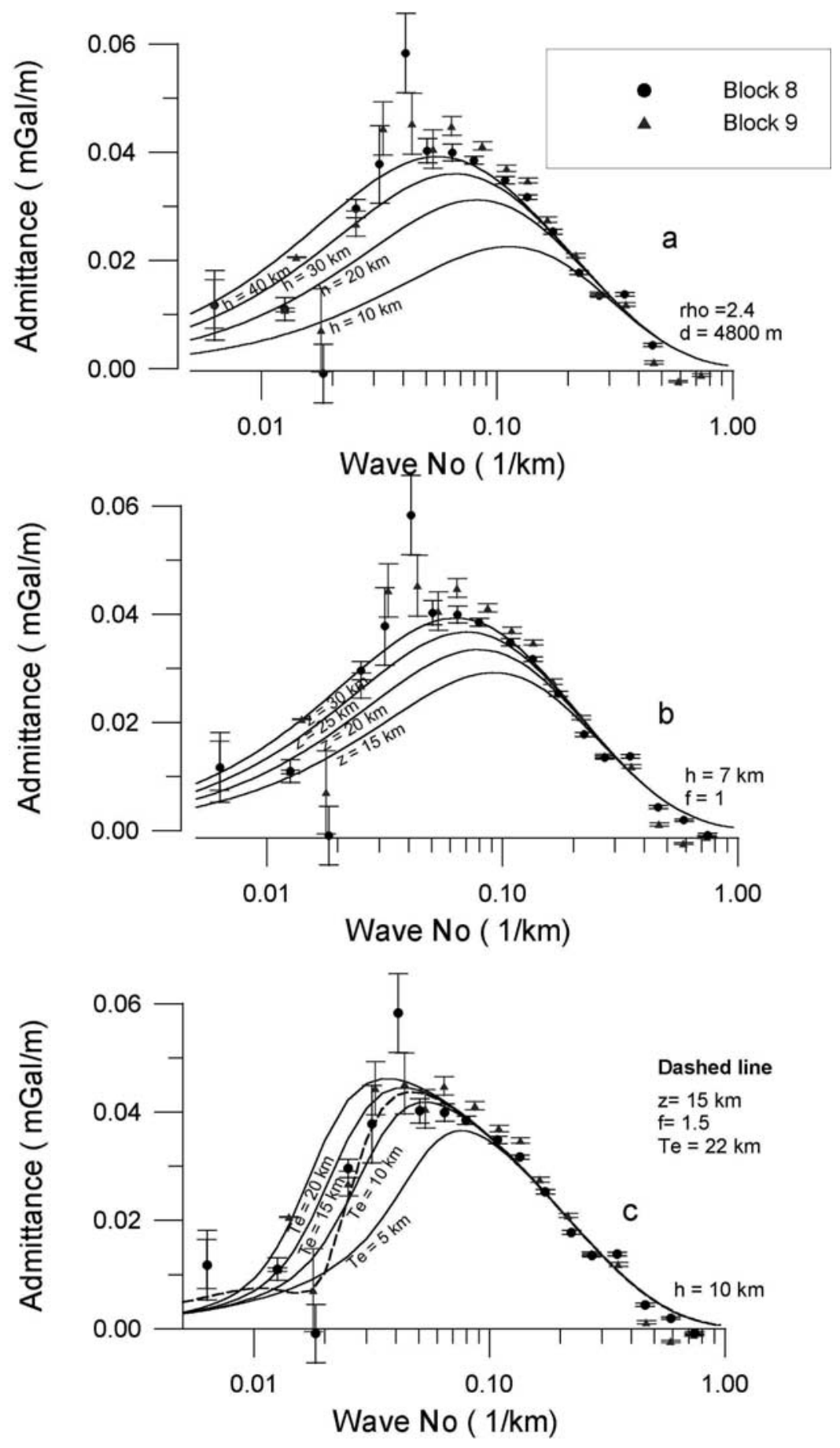

Figure 11. (a) Plots of theoretical admittance based on Airy model for various crustal thicknesses $(h)$. Computed admittance values for block 7 (solid rectangles) and block 8 (solid dots) with standard error bar are also plotted. Other parameters are written to the corresponding plots. (b) Plots of theoretical admittance for various compensating depths $(z)$ and zero plate thickness $(T e)$ based on plate model of equal ratio of surface to subsurface loading $(f=1)$. Other details are as in Figure 11a. (c) Plots of theoretical admittance for various thickness of plate and crustal thickness of $10 \mathrm{~km}$ based on plate model of surface loading only. Best fit (block dashed line) represents theoretical admittance for $T e=22 \mathrm{~km}$, compensating depth $(z)$ of $15 \mathrm{~km}$ and ratio of subsurface to surface load $(f=1.5)$. Other details are as in Figure 11a.

plate in the northern part (north of $2^{\circ} \mathrm{S}$ ), volcanism at platelate (transition between two plate or small plate) in the central part $\left(2^{\circ} \mathrm{S}\right.$ to $\left.15^{\circ} \mathrm{S}\right)$ and volcanism at a plate margin or along transform fault in the southern part (south of $15^{\circ} \mathrm{S}$ ). However, flexural compensation of the southern block may not fit the model of Royer et al. [1991], which suggests loading on a transform fault. The estimated value of EET for the southern part is higher 
Earlier Studies

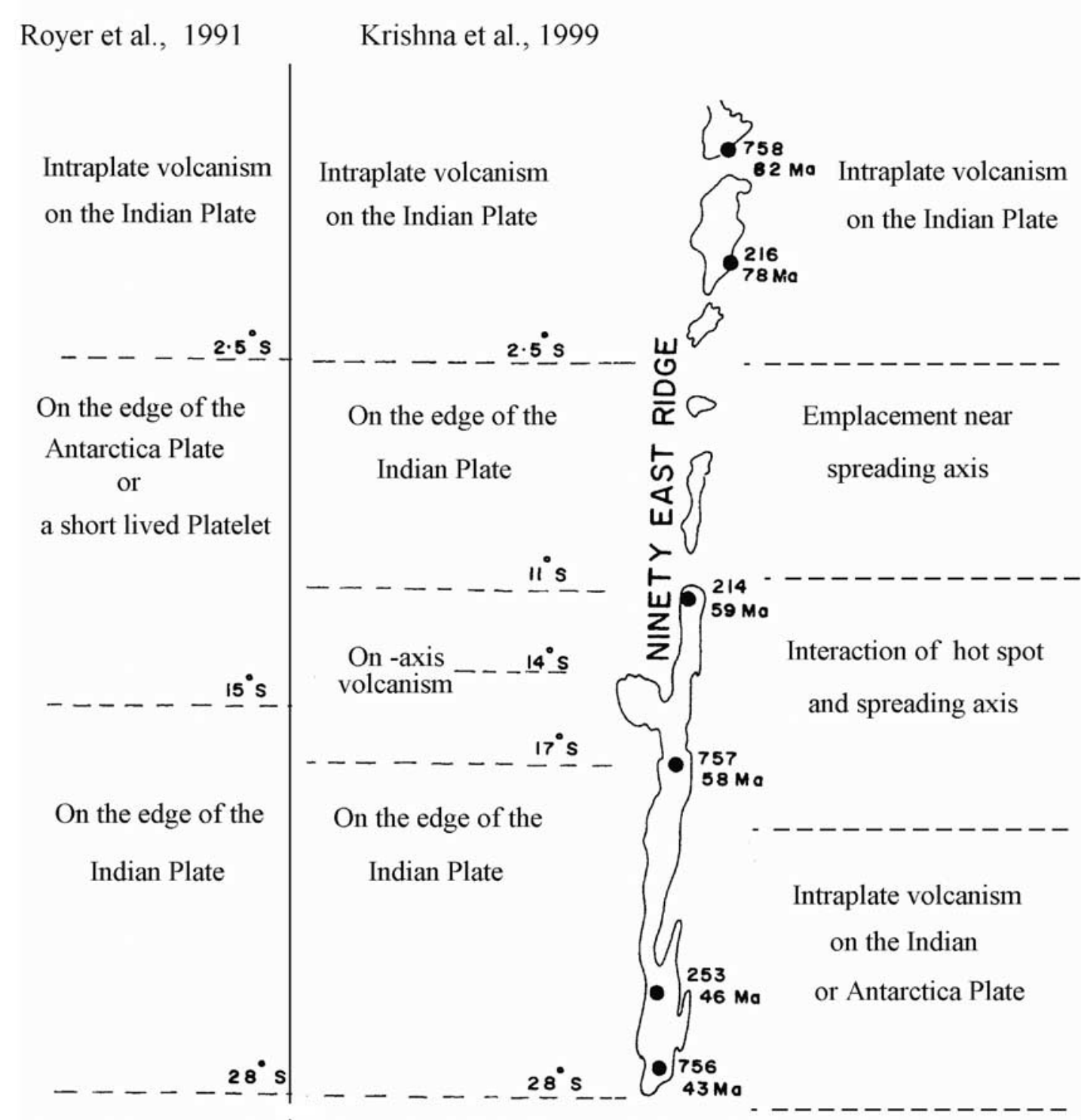

Present Study

Figure 12. Proposed evolutionary model of NER and its comparison with earlier models.

than value generally observed over mid oceanic ridges and comparable to the values observed over old fracture zones [Watts and Zhong, 2000]. We suggest that the southern part was emplaced over old lithosphere, such as along fracture zone on the Antarctic/Australian plate rather than along an active transform fault. Support for our suggestion comes from abandoned spreading center west of NER that joins the southeast Indian ridge to the west of NER [Krishna et al., 1995, 1999] and signature of an abandoned spreading center near south east Indian ridge in the west of NER (P. Patriat, personal communication, 2000). Gravity lows observed in the west of NER (Figures 6b and 6c) can also support this as it is noticed that the abandoned spreading center and its transform fault are associated with gravity low [Hébert, 1998].

[16] Our model requires subsurface loading as large as the surface load and differs with the previous model of Detrick and Watts [1979]. However, a closer examination of their admittance plot [Detrick and Watts, 1979, Figure 10] reveals that observed admittance, at large wavelengths matches well with crustal thickness of $30 \mathrm{~km}$, which is quite high for oceanic region. We made a similar observation for the central block (Figure 10) and as Grevemeyer and Flueh [2000] did in the same area. We preferred a model with a small crustal thickness and subsurface loading, which could also explain the observed admittance. This will agree with reported high velocity in the lower crust [Francis and Raitt, 1967; Grevemeyer et al., 2001], low velocity in upper mantle [Souriau, 1981; Debayle and Léveque, 1997], and additional mass anomalies envisaged to explain the observed gravity data [Detrick and Watts, 1979]. High-velocity and high-density material in the lower crust may correspond to accreted magma as inferred under oceanic hot spot [ten Brink and Brocher, 1987; Caress et al., 1995]. Low-density material in the upper mantle is generally interpreted as residue of a partial melt 
zone [Morgan and Forsyth, 1988]. This indicates that only a part of total volume of magma is intruded in the lower crust at the time of formation of the bathymetric feature. The variation in the total volume of magma (surface plus subsurface loading) along the ridge can be attributed to the relative motion of Indian/Antarctic plate to the hot spot and position of spreading center to the hot spot. When relative motion was large, the amount of loading on the plate could have been less and vice versa. On basis of magnetic anomaly, Curray et al. [1982] have suggested a relative large plate motion in the northern part $(11.8 \mathrm{~cm}$ $\left.\mathrm{yr}^{-1}\right)$ compared to the southern part $\left(10.8 \mathrm{~cm} \mathrm{yr}^{-1}\right)$ and further less in the central part $\left(9.2 \mathrm{~cm} \mathrm{yr}^{-1}\right)$ with a possibility of pause near Osborn Knoll $\left(15^{\circ} \mathrm{S}\right)$. These inferences are compatible with our results.

\subsection{Central Part of NER $\left(10^{\circ}-20^{\circ} \mathrm{S}\right)$ : Hot Spot Ridge Interaction?}

[17] The part of the NER between $10^{\circ}$ and $20^{\circ}$ latitude is locally compensated with a large amount of subsurface loading as high as twice the surface loading. Large values of subsurface loading can cause buoyancy uplift and would result in a large topography $(\sim 1 \mathrm{~km}$ compared to other parts) observed in this region $\left(10^{\circ}-20^{\circ}\right.$ latitude). A low value of EET, large topography, and large subsurface loading can be explained by presence of a hot spot very close to a spreading center in this region. Plate tectonic reconstruction also suggests that at 60 m.y., Osborn Knoll $\left(15^{\circ} \mathrm{S}\right)$ was over a spreading center and near a hot spot [Royer et al., 1991]. The signature of the abandoned Wharton spreading center $(60-40$ m.y.) was also reported from this area [Krishna et al., 1995]. In addition, the age difference from north to south in this part is very small (ODP sites 214 and 757; Figure 2) and an anomalous paleolatitude (i.e., paleolatitude which does not correspond to Kerguelen hot spot as observed for other drilling sites) was observed on ODP drilling site 757 [Coffin, 1992]. Interaction of a hot spot with a spreading center may cause excess and complex nature of volcanism, different from volcanism from single source and can explain the observation of anomalous paleolatitude at drilling site 757. These observations may suggest that Asborn Knoll, an east-west large topography, was formed when a hot spot was under spreading center as interaction of a hot spot with a spreading center results in anomalous crustal thickness and bathymetry [Schilling, 1991; Ito and Lin, 1995] and excess magmatism [Cannat et al., 1999]. Thus all these observations and paleo reconstruction [Royer et al., 1991; Krishna et al., 1999] suggest that the Kerguelen hot spot which formed the NER, interacted with Wharton fossil spreading center that was active during 60-40 m.y.

\subsection{Conclusions}

[18] The following conclusions can be drawn on the basis of this study.

1. Satellite-derived data can be used to infer isostatic mechanism of a particular oceanic region. An evolutionary model of NER based on analysis of satellite-derived gravity and bathymetry data is presented in Figure 12.

2. The mode of isostatic compensation differs for different parts of NER. At least three distinctions can be made: northern part $\left(0-10^{\circ} \mathrm{N}\right)$, central part $\left(0-20^{\circ} \mathrm{S}\right)$ and southern part $\left(20^{\circ}-30^{\circ} \mathrm{S}\right)$. Differences in isostatic behavior can be attributed to the differences in the age of the crust on which NER was formed.

3. Northern and southern parts were emplaced on relatively older lithosphere compared to central part, which might have been emplaced on or near to the spreading center. These differences can be attributed to off axis shift in the hot spot, which formed NER.

4. Our results suggest that underplating might play an essential role in the emplacement process of large volcanic plateaux and provinces.

5. Locally compensated large topography, thick underplated crust in the central part (near Osborn Knoll), might have been evolved due to interaction of hot spot with spreading ridge axis (Figure 12).

[19] Acknowledgments. Manuscript was improved considerably by the thoughtful reviews of $\mathrm{C}$. Ebinger (AE) and anonymous reviewers. Discussions with P. Patriat, C. Deplus, H. Hébert, and C. Widiwijayanti have been very helpful, and we acknowledge them. We thank E. Burov for his code for direct modeling. We thank I. Grevemeyer for providing a preprint of their paper on deep seismic results before publication. GMT software was used for preparing one of the figures. One of the authors (V.M.T.) wishes to thank DST, New Delhi, and H. K. Gupta, Director, NGRI, Hyderabad, India, for financial support and encouragement, respectively.

\section{References}

Andersen, O., and P. Knudsen, Global marine gravity field from the ERS-1 and GEOSAT geodetic mission altimetry, J. Geophys. Res, 103, 81298137, 1998.

Bowin, C., Origin of the Ninetyeast Ridge from studies near the equator, J. Geophys. Res., 78, 6029-6043, 1973.

Cannat, M., et al., Mid-Atlantic Ridge-Azores hotspot interaction: Along axis migration of a hotspot derived event of enhanced magmatism 10 to 4 Ma ago, Earth Planet. Sci. Lett., 173, 257-269, 1999.

Caress, D., M. K. Mcnutt, R. S. Detrick, and J. C. Mutter, Seismic imaging of hotspot related crustal underplating beneath the Marquesas Islands, Nature, 373, 600-603, 1995.

Cochran, J. R., An analysis of isostasy in the world's ocean, 2, Mid-ocean ridge crest, J. Geophys. Res., 84, 4713-4729, 1979.

Coffin, M. F., Emplacement and subsidence of Indian Ocean plateau's and submarine ridges, in Synthesis of Results From Scientific Drilling in the Indian Ocean, Geophysical Monograph, vol. 70, edited by R. A. Duncan et al., pp. 115-125, AGU, Washington, D. C., 1992.

Crough, S. T., Hotspot swells, Annu. Rev. Earth Planet. Sci., 11, 165-193, 1983.

Curray, J. R., J. E. Frans, D. G. Moore, R. W. Raitt, The Indian Ocean: Aseismic ridges, spreading centers, and oceanic basins, in The Ocean Basins and Margins, vol. 6, The Indian Ocean, edited by A. E. M. Nairn and F. G Stehli, pp. 399-447, Plenum, New York, 1982.

Debayle, E., and J. J. Léveque, Upper mantle heterogeneities in the Indian Ocean from waveform inversion, Geophys. Res. Lett., 24, 245-248, 1997.

Detrick, R. S., and A. B. Watts, An analysis of isostasy in the world's ocean, 3, Aseismic Ridges, J. Geophys. Res, 84, 3637-3653, 1979.

Diament, M., and J. Goslin, Emplacement of the Marion duresne, Lena and $\mathrm{Ob}$ Seamounts (South Indian Ocean) from a study of Isostasy, Tectonophysics, 121, 253-262, 1986.

Duncan, R. A., The age distribution of volcanism along aseismic ridges in the eastern Indian Ocean, Proc. Ocean Drill. Program Sci. Results, 121, 507-517, 1991 .

Forsyth, D. W., Subsurface loading and estimates of the flexural rigidity of continental lithosphere, J. Geophys. Res., 90, 12,623-12,632, 1985.

Francis, T. J. G., and R. W. Raitt, Seismic refraction measurements in the southern Indian Ocean, J. Geophys. Res., 72, 3015-3042, 1967.

Frey, F., and D. Weis, Temporal evolution of the Kerguelen plume; Geochemical evidence from approximately 38 to 82 Ma lavas forming the Ninetyeast Ridge, Contrib. Mineral. Petrol., 121, 12-28, 1995.

Grevemeyer, I., and E. R. Flueh, Crustal-Underplating and its implications for subsidence and state of isostasy along the Ninetyeast Ridge hotspot trail, Geophys. J. Int., 142, 643-649, 2000. 
Grevemeyer, I., E. R. Flueh, C. Reichert, J. Bialas, D. Klaschen, and C. Kopp, Crustal architecture and deep structure of the Ninetyeast Ridge hotspot trail from active-source ocean bottom seismology, Geophys. J. Int., 144, 414-431, 2001.

Hahn, A., E. G. Kind, and D. C. Mishra, Depth calculation of magnetic sources by means of Fourier amplitude spectra, Geophys. Prospect., 24, $287-308,1976$.

Hébert, H., Etudes géophysiques d' une dorsale naissante (dorsale d 'Aden a ' $1^{\prime}$ Ouest de $46^{\circ}$ E) et d' une dorsale fossile (dorsale de Wharton): Implications sur les processus de I' accrétion océanique, et la déformation intraplaque de l'Océan Indien, Thése de doctorat, Univ. Paris 7, Paris, France, 1998.

Hébert, H., C. Deplus, and M. Diament, Origin of the 90 E ridge and Investigator ridge deduced from the analysis of bathymetric and gravimetric data, C. R. Acad. Sci., Ser. II, 323, 105-112, 1996.

Ito, G., and J. Lin, Oceanic spreading center-hotspot interaction: Constraints from along - isochron bathymetric and gravity anomalies, Geology, 23, 657-660, 1995.

Ito, G., and A. Taira, Compensation of the Ontong Java plateau by surface and subsurface loading, J. Geophys. Res, 105, 11,171-11,183, 2000.

Krishna, K. S., D. Gopal Rao, M. V. Ramana, V. Subrahmanyam, K. V. L. N. S. Sarma, A. I. Pilipenko, V. S. Shcherbakov, and I. V. Radhakrishna Murthy, Tectonic model for the evolution of oceanic crust in the northeastern Indian Ocean from the Late Cretaceous to the early Tertiary, J. Geophys. Res., 100, 20,011-20,024, 1995.

Krishna, K. S., D. Gopal Rao, L. V. Subba Raju, and A. K. Chaubey, Paleocene on-spreading-axis hotspot volcanism along the Ninetyeast Ridge: An interaction between the kerguelen hotspot and the Wharton spreading center, Proc. Indian Acad. Sci. Earth Planet. Sci., 108, $255-$ 267, 1999.

Liu, C. S., J. R. Curray, and J. M. McDonald, New constraints on the tectonic evolution of eastern Indian Ocean, Earth Planet. Sci. Lett., 65, $331-342,1983$.

Louden, K. E., and D. W. Forsyth, Crustal structure and isostatic compensation near the Kane fracture zone from topography and gravity measurements, I, Spectral analysis approach, Geophys. J. R. Astron. Soc., 68, $725-750,1982$.

Luyendyk, B. P., and W. Rennick, Tectonic history of aseismic ridges in the eastern Indian Ocean, Geol. Soc. Am. Bull., 88, 1347-1356, 1977.

Lyons, S. N., D. T. Sandwell, and W. H. F. Smith, Three-dimensional estimation of elastic thickness under the Louisville ridge, J. Geophys. Res., 105, 13,239-13,252, 2000.

Macario, A., A. Malinverno, and W. F. Haxby, On the robustness of elastic thickness estimates obtained using the coherence method, J. Geophys. Res., 100, 15,163-15,172, 1995.

McAdoo, D. C., and D. T. Sandwell, On the source of cross-grain lineations in the central Pacific gravity field, J. Geophys. Res., 94, 9341-9352, 1989.

McKenzie, D. P., and C. Bowin, The relationship between bathymetry and gravity in the Atlantic Ocean, J. Geophys. Res., 81, 1903-1915, 1976.

McKenzie, D. P., and D. Fairhead, Estimates of the effective elastic thickness of the continental lithosphere from Bouguer and free air gravity anomalies, J. Geophys. Res., 102, 27,523-27,552, 1997.

McNutt, M. K., and L. Shure, Estimating the compensation depth of the Hawaiian swell with linear filters, J. Geophys. Res., 91, 13,915-13,923, 1986.
Morgan, J. P., and D. W. Forsyth, Three-dimensional flow and temperature perturbations due to a transform offset: Effect on oceanic crustal and upper mantle structure, J. Geophys. Res., 93, 2955-2966, 1988.

Morgan, W. J., Plate motions and deep mantle convection Bull, Am. Assoc. Pet. Geol., 56, 203-213, 1972.

National Geophysical Data Center, Data announcement 88-MGG-02, Digital relief of the surface of the Earth, NOAA, Boulder, Colo., 1988.

Parker, R. L., The rapid calculation of potential anomalies, Geophys. J. R. Astron. Soc., 31, 447-455, 1972.

Rapp, R. H., Comparison of altimetry derived and ship gravity anomalies in the vicinity of the Gulf of California, Mar. Geod., 21, 245-259, 1998.

Royer, J. Y., and D. T. Sandwell, Evolution of the eastern Indian Ocean since the late Cretaceous: Constraints from GEOSAT altimetry, J. Geophys. Res., 94, 13,755-13,782, 1989.

Royer, J. Y., J. W. Peirce, and J. K. Weissel, Tectonic constraints on the hotspot formation of Ninetyeast Ridge, Proc. Ocean Drill. Program Sci. Results, 121, 763-775, 1991.

Sandwell, D. T., Geophysical applications of satellite altimetry, U.S. Natl. Rep. Int. Union Geod. Geophys., 1987-1990, Rev. Geophys., 29, 132137, 1991.

Schilling, J. G., Fluxes and excess temperature of mantle plumes inferred from their interaction with migrating mid-ocean ridges, Nature, 352, 397-403, 1991.

Schlich, R., The Indian Ocean: Aseismic ridges, spreading centers, and oceanic basins, in The Ocean Basins and Margins, vol. 6, The Indian Ocean, edited by A. E. M. Nairn and F. G Stehli, pp. 51-148, Plenum, New York, 1982.

Sclater, J. G., and R. L. Fisher, Evolution of the east central Indian ocean, with emphasis on the tectonic setting of the Ninetyeast Ridge, Geol. Soc. Am. Bull., 85, 683-702, 1974.

Smith, W. H. F., and D. T. Sandwell, Global seafloor topography from Satellite altimetry and ship depth soundings, Science, 277, 1956-1962, 1997.

Souriau, A., The upper mantle beneath Ninetyeast Ridge and Broken Ridge, Indian Ocean from surface waves, Geophys. J. R. Astron. Soc., 67, 359374, 1981 .

Spector, A., and F. S. Grant, Statistical models for interpreting aeromagnetic data, Geophysics, 35, 293-302, 1970.

ten Brink, U. S., and T. M. Brocher, Multichannel seismic evidence for a subcrustal intrusive complex under Oahu and a model for Hawaiian volcanism, J. Geophys. Res., 92, 13,687-13,707, 1987.

Watts, A. B., An analysis of isostasy in the world's ocean, 1, HawaiianEmperor Seamount chain, J. Geophys. Res., 83, 5989-6004, 1978.

Watts, A. B., and S. Zhong, Observations of flexure and rheology of oceanic lithosphere, Geophys. J. Int., 142, 855-875, 2000.

Watts, A. B., J. H. Bodine, and N. M. Ribe, Observations of flexure and geological evolution of the Pacific Ocean basin, Nature, 283, 532-537, 1980 .

M. Diament and S. C. Singh, Institut de Physique du Globe de Paris, 4 Place Jussieu, F-75252 Paris, France. (diament@ipgp.jussieu.fr; singh@, ipgp.jussieu.fr)

V. M. Tiwari, National Geophysical Research Institute, P.O. Bag 724, Uppal Road, Hyderabad -500 007, India. (vmtiwari@yahoo.com) 